\title{
Gender Discrimination in Nepal: Does It Vary Across Socio- Demographics?
}

Anil Kumar Guptaㄹ, Poonam Kumari Kanu, Bishnu Prasad Lamsal cdps10gupta@gmail.com

\begin{abstract}
Gender discrimination is a pressing issue in gender research across the globe. While the Government of Nepal has taken several measures to address gender discrimination it remains prevalent at all levels of society. This paper examines the prevalence of gender discrimination in Nepal and its variability based on socio-demographic status. It employs micro-level data generated by Nepal National Governance Survey 2017/18 was used and analyzed through a logistic regression model. The results showed that the experience of gender-based discrimination varies based on socio-demographic factors including: gender, age, urban/rural, education, and economic status. Women's experiences of discrimination or marginalization vary based on their intersectional identity. The deeply ingrained patriarchal gender ideology in Nepal, driven by traditional cultural values and practices, perpetuates discrimination along gender lines.
\end{abstract}

Keywords: Discrimination, gender, patriarchal, women, Nepal.

Copyright ${ }^{\odot} 2021$ by Author(s)

This work is licensed under a Creative Commons Attribution-ShareAlike 4.0 International License. All writings published in this journal are personal views of the authors and do not represent the views of this journal and the author's affiliated institutions.

\section{HOW TO CITE:}

Gupta, Anil Kumar \& Poonam Kumari Kanu et al. "Gender Discrimination in Nepal: Does It Vary Across Socio-Demographics?" (2021) 1:2 Contemporary Sociological Issues 145165.

$\begin{array}{llll}\text { Submitted } & \text { :December 9, } 2020 & \text { Accepted } & \text { :July 25, 2021 } \\ \text { Revised } & \text { :January 22, 2021 } & \text { Publish } & \text { : August 31, 2021 }\end{array}$

${ }^{1}$ Correspondent Author 


\section{INTRODUCTION}

Gender inequality is declining globally, albeit at a sluggish rate, but it's pervasive effects can be seen in every country, to varying degrees. Gender discrimination is a universal societal problem and is particularly prevalent in developing Asian and African nations. Such discrimination not only harms human civilization and the current global economy, but has serious implications for future generations. ${ }^{2}$ Gender discrimination is common in everyday experiences in developing countries. ${ }^{3}$ As per the Nepal Demographic and Health Survey ${ }^{4}$, in Nepal, 22\% of women aged 15-49 have experienced gender discrimination in the form of physical violence, with $7 \%$ of these constituting sexual violence. The most common type of spousal violence is physical (23\%), followed by emotional (12\%). Sixty-six percent of women who encountered some form of physical or sexual abuse did not seek support or speak to anyone about preventing or ending the abuse they endured. As per the Nepal National Governance Survey ${ }^{5}$, just over one in ten people $(11 \%)$ states that they, or their family members, have experienced gender-based discrimination in the past year. This evidence shows how prevalent gender discrimination is.

Nepal is ranked 101st of 153 countries with a score of 0.680 on the Global Gender Gap Index ${ }^{6}$ compared to its 2006 ranking at lllth with a score of 0.548 . Although Nepal's position has improved in the Index, gender disparity still exists. Both vsible and invisible discrimination against women continues to prevail. State and nonstate efforts to eliminate gender discrimination have experienced little success. Fighting gender-based discrimination is complex and challenging because of how deeply it is embedded in social and cultural traditions, manifesting in different forms in both the private and public spheres. The inherent patriarchal orientation of society, conditioned by social and cultural norms and structures systematically discriminates against women.

'Gender' is a socially constructed concept that relates to society's idea of what it means to be a man or a woman. ${ }^{7}$ These terms are used to help understand social structures and interactions that negotiate a persons position and role within society.

\footnotetext{
2 Bishnu Adhikari, "Gender Inequality and the Problem with Girls' School Attendance in Nepal: A Qualitative Perspective of Patriarchal Nepalese Practice (Unpublished Master's Thesis)" (Norway, Nord University, 2013), https://bit.ly/3kx2PFU.

${ }^{3}$ Newman Wadesango, "Is Gender Equality Still an Issue? Tensions and Contradictions Embeding the Work of Feminists Today," Journal of Social Sciences 26, no. 3 (1 Maret 2011): 163-69.

${ }^{4}$ Ministry of Health- MOH/Nepal, New ERA/Nepal, dan ICF, "Nepal Demographic and Health Survey 2016," 1 November 2017, https://bit.ly/2ICGSIg.

${ }^{5}$ Nepal Administrative Staff College, "Nepal national governance survey 2017/18" (Jawalakhel, Lalitpur: Nepal Administrative Staff College, 2018), https://bit.ly/2K8LFCb.

${ }^{6}$ World Economic Forum, "Global Gender Gap Report 2020" (Cologny, Switzerland: World Economic Forum, 2020), https://bit.ly/36sE60s.

${ }^{7}$ Janaki Nair, Women and Law in Colonial India: A Social History (New Delhi: Kali for Women and The National Law School of India, 1996), https://bit.ly/2WF6Pl4.
} 
Crucially, gender is not reducible to differences in a person's biological sex. ${ }^{8}$ Deeply ingrained patriarchal attitudes and socio-cultural norms and values open space for discrimination along gender lines which often pose specific challenges for women and cementing their marginalized social position, preventing access to certain positions and opportunities. ${ }^{9}$ Women are systematically discriminated against within patriarchal societies. Patriarchy, according to Barlas ${ }^{10}$, is a sexual segregation strategy that favors males by turning biological sex into a political gender that gives preference to men when women are different (unequal), less than or otherwise. Patriarchy is a socially constructed system and ideology preoccupied with gender conditions, consistently favouring the masculine (men) ideal over the feminine (women), affecting choice profiles and opportunities based on these ideals." The patriarchal culture in Nepal contributes to the continuation of gender discrimination. Women in Nepal experience variable degrees of discrimination based on their intersecting identities, including age, race, (dis)ability and economic status.

Gender inequality and discrimination severely inhibits women's access to work, travel, marriage, divorce and engagement in socio-cultural, economic, and political activities. ${ }^{12}$ Women experience negative effects of inequality, prejudice, and abuse. ${ }^{13}$ Women's position has worsened due to acutely ingrained hegemonic views on gender. In this context, this paper examines the prevalence of gender discrimination in Nepal by socio-demographic status, using Nepal's National Governance Survey 2017/18 data set. This paper generates empirical evidence, supplemented by scholarly discussion on gender discrimination in Nepal relating to socio-demographic factors.

\section{LITERATURE REVIEW}

\section{A. Gender Discrimination}

Discrimination can be understood as unfavourable, biased, and negative treatment based on personal attributes. Dipboye and Colella ${ }^{14}$ define discrimination as undue conduct that transfers biases and stereotypes into action. Gender discrimination relates to unfair treatment based on a person's perceived gender. It can be direct or

\footnotetext{
8 Anita Shrestha dan R. Gartoulla, "Socio-cultural Causes of Gender Disparity in Nepalese Society," Journal of Advanced Academic Research 2, no. 1 (2015): 100-111.

9 Adel SZ Abadeer, Norms and Gender Discrimination in the Arab World (United States: Palgrave Macmillan, 2015), https://bit.ly/2Va2WAX.

${ }^{10}$ Asma Barlas, "Believing women" in Islam: unreading patriarchal interpretations of the Qur'ān, lst ed (United States: University of Texas Press, 2002), https://bit.ly/36wBFu8.

"l S. Walby, Theorizing Patriarchy (Cambridge USA: Blackwell Publisher, 1990), https://bit.ly/3xgw06P; Hannelie J. Wood, "Gender inequality: The problem of harmful, patriarchal, traditional and cultural gender practices in the church," HTS Teologiese Studies / Theological Studies 75, no. 1 (12 Maret 2019): 8. ${ }^{12}$ Abadeer, Norms and Gender Discrimination in the Arab World.

${ }^{13}$ CN Shankar Rao, Sociology: Principles of Sociology with an Introduction to Social (Chand \& Company Ltd., 2008).

14 Robert L. Dipboye dan Adrienne Colella, Discrimination at Work: The Psychological and Organizational Bases (North Carolina: Lawrence Erlbaum Associates Publishers, 2005).
} 
indirect, wholly or partly unfair treatment and infringement of rights based on gender. The Convention on the Elimination of all Forms of Discrimination Against Women ${ }^{15}$ defines discrimination against women as:

"...any distinction, exclusion or restriction made based on sex which has the effect or purpose of impairing or nullifying the recognition, enjoyment or exercise by women, irrespective of their marital status, on a basis of equality of men and women, of human rights and fundamental freedoms in the political, economic, social, cultural, civil or any other field" (Article 1).

Generally speaking, gender inequality or discrimination is the term used for women as they find the lowest and weakest part of society. ${ }^{16}$ Indeed, women are not socially or culturally weak, nor mentally vulnerable. Sharma ${ }^{17}$ argues that gender discrimination is implied to apply only to women, as they are the only dupes of gender discrimination. Further, gender discrimination is socially created, and can be modified over time and between cultures. Shastri ${ }^{18}$ argues, along the same lines as Sharma ${ }^{19}$, that gender discrimination is socially and culturally determined.

As such, this paper defines gender discrimination as biases toward and unfair treatment of individuals based on their gender. The majority of gender discrimination is directed at women. Women are discriminated against and treated unequally in comparison to their male peers. Gender discrimination may be wholly or partly unfavourable towards women in their spheres of life.

\section{B. Socialization and Gender Discrimination}

Socialization takes place during childhood, where boys and girls learn about sexual behaviour. ${ }^{20}$ Gender socialization relates to learned beliefs and behaviours related to secific ideas and characteristics socially ascribed to gender roles. ${ }^{21}$ In this sense, it provides a major backdrop from which children learn what their society considers being a 'man' or a 'woman'.22 Gender roles are constructed and reinforced culturally and institutionally. Children learn about gender roles and identities at home; manhood is often associated with power and authority while womanhood is closely

\footnotetext{
${ }^{15}$ United Nations, "Convention on the elimination of all forms of discrimination against women," 1979, https://bit.ly/2JWVLpx.

${ }^{16}$ Samidha Pokharel, "Gender Discrimination: Women Perspective," Nepalese Journal of Development and Rural Studies 5, no. 2 (1 Januari 2008): 80-87.

${ }^{17}$ Indu Sharma, "Gender discrimination and status of women in India," Contemporary Social Sciences 27, no. 1 (2018): 105-14.

18 Andrey Shastri, "Gender Inequality and Women Discrimination," IOSR Journal of Humanities and Social Science 19, no. 11 (2014): 27-30.

${ }^{19}$ Sharma, "Gender discrimination and status of women in India."

${ }^{20}$ Abeda Sultana, "Patriarchy and Women's Subordination: A Theoretical Analysis," Arts Faculty Journal

4 (13 Desember 2012): 1-18.

${ }^{21}$ Anthony Giddens, Sociology (Cambridge: Polity Press, 1993).

${ }^{22}$ Charles G. Morris, Psychology: An Introduction (New Jersey: Prentice-Hall, Inc, 1996).
} 
linked to inferiority and subjection. ${ }^{23}$ Gender differences are determined by sociocultural expectations and beliefs, and are learned through socialization. ${ }^{24}$ These ideas are often passed directly from parents to children, as well as through society more broadly through systems of education, politics, economy, legislation, culture, and tradition..$^{25}$ Gender roles are structured hierarchically, with men wielding authority and control over women, and women subjection ideological and material bases. ${ }^{26}$ Boys learn how to uphold their authority over girls, while girls learn how to comply. ${ }^{27}$

Patriarchy is bred through socialization, which starts in the family and spreads in several parts of society like religion, education, economy, and politics. ${ }^{28}$ To maintain structures of male supremacy and dominance in society, patriarchies reproduce 'masculine' ideals in the public sphere, systematically favouring them over their 'feminine' counterparts which are generally confined to the private sphere. ${ }^{29}$ Social institutions such as peer groups, society, schools, media directly or indirectly foster deeply ingrained patriarchal traditions and practices reinforce gender roles, responsibilities, differences and discrimination. ${ }^{30}$ Children's behaviour later in life is conditioned by the gender roles and ideologies they learn growing up. If children are socialized in a non-discriminatory manner, it boosts fairness between men and women. Socialization is the underlying cause of gender differences and discrimination. ${ }^{31}$ Nepal's social values and customs systematically favours men, ensuring higher degrees of recognition, power and dominace through which they are able to control and limit women's participation in society. This is reinforced through processes of patriarchal socialization which reifies gender differences and discrimination. There is a pressing need for educational reform, both with family units as well as society more broadly, to empower girls to fight for equality with their male peers. This education must also target boys, teaching them about the oppressive structures of patriarchal power in society and its deeply ingrained gender hegemony, working toward deconstructing these beliefs.

\footnotetext{
${ }^{23}$ Usha Ram, Lisa Strohschein, dan Kirti Gaur, "Gender Socialization: Differences between Male and Female Youth in India and Associations with Mental Health," International Journal of Population Research, 27 April 2014, 1-11, https://doi.org/10.1155/2014/357145.

${ }^{24}$ Anil Kumar Gupta, "Significance of Girl Education: Parents' Perception from Rural Madhesh of Nepal," Journal of Management and Development Studies 29 (28 September 2019): 61-68.

${ }^{25}$ KU Omoyibo dan BI Ajayi, "Understanding gender and global Africa: A critical perspective," Gender and Behaviour 9, no. 1 (28 Juni 2011): 3729-51, https://doi.org/10.4314/gab.v9il.67470.

${ }^{26}$ Nyambura Njoroge, Gender Justice, Ministry and Healing: A Christian Response to the HIV Pandemic (New North Road London: Progression, 2009), https://bit.ly/2VceinL.

${ }^{27}$ Ram, Strohschein, dan Gaur, "Gender Socialization: Differences between Male and Female Youth in India and Associations with Mental Health."

${ }^{28}$ Maureen Kambarami, Femininity, Sexuality and Culture: Patriarchy and Female Subordination in Zimbabwe (South Africa: ARSRC, 2006), https://bit.ly/3j9i2hL.

${ }^{29}$ Sultana, "Patriarchy and Women's Subordination: A Theoretical Analysis."

${ }^{30}$ Farai Maunganidze, "Dealing with gender-related challenges: A perspective of Zimbabwean women in the practice of law," ed. oleh Antonio Belso-Martinez, Cogent Business \& Management 7, no. 1 (1 Januari 2020): 18.

${ }^{31}$ Maunganidze.
} 


\section{International Commitments}

A number of international seminars, conventions, and conferences have been held globally to work towards gender justice. The Universal Declaration of Human Rights ${ }^{32}$ specifies that one should not be discriminated against based on their sex. The Conference on Women's Political Rights ${ }^{33}$ explicitly safeguards women's rights. This convention acknowledges that everyone has the right to participate, directly or indirectly, in government and equal entry into the public services. This conventions also works toward the balancing of men and women in access to and realisation of political rights. The Convention on Married Women's Nationality ${ }^{34}$ provides a legal structure to regulate the nationality of married women. The Convention retains the nationality of married women to maintain or revoke citizenship on an equal basis with men. A landmark convention for the protection of women's rights is the CEDAW. ${ }^{35}$ The Convention defines discrimination against women and sets out a national plan of action to eradicate discrimination. The Convention acknowledged and discussed all types of discrimination, whether found in law, regulations, and guidelines or performance. $^{36}$

The Declaration on the Elimination of Violence against Women ${ }^{37}$ was the first global contract to explicitly tackle violence against women, establishing a legal basis for action at both national and international levels. It describes violence as any physical, sexual or psychological abuse of women/girls happening in the home, society, and state. ${ }^{38}$ Four world conferences relating to women have been organized by the United Nations: the first was held in Mexico in 1975; the second in Copenhagen, 1980; the third in Nairobi, in 1985; and the fourth in Beijing, 1995. From the Beijing Conference a fiveyear review, the Beijing Platform for Action 1995, was adopted highlighting 12 key areas of action to ensure greater equality. The International Conference on Population and Development ${ }^{39}$ focused on reproductive health and rights, as well as equality and empowerment for women. Poverty reduction, universal primary education, gender equality, the empowerment of women, and improvements in maternal health are some of the critical themes in the Millennium Development Goals ${ }^{40}$ relating to gender. Likewise, the Sustainable Development Goals ${ }^{41}$ are dedicated to achieving gender

\footnotetext{
32 United Nations, "Universal declaration of human rights," 1948, https://bit.ly/3nkd0Qb.

${ }^{33}$ United Nations, "Conference on women's political rights," 1952, https://bit.ly/2UnJk8e.

${ }^{34}$ United Nations, "Convention on married women's nationality," 1957, https://bit.ly/2HOybHv.

${ }^{35}$ United Nations, "Convention on the elimination of all forms of discrimination against women."

${ }^{36}$ Sharma, "Gender discrimination and status of women in India."

37 United Nations, "Declaration on the elimination of violence against women," 1993, https://bit.ly/36xbCCU.

${ }^{38}$ Anna King, "UN Declaration on the Elimination of Violence against Women," dalam The Encyclopedia of Women and Crime, 1-2 (American Cancer Society, 2019), 1-2, http://dx.doi.org/10.1002/9781118929803.ewac0505.

${ }^{39}$ United Nations Population Found, "International conference on population and development," 1994, https://bit.ly/3kyq0zI.

${ }^{40}$ United Nations, "Millennium development goals," 2000, https://bit.ly/36xxVZf.

${ }^{41}$ United Nations, "Sustainable development goals," 2015, https://bit.ly/3kvtYJp.
} 
equality and empowering women and girls, which are essential and related to each of the 17 goals. In addition to these, there are many more international conventions, conferences, and declarations for fostering gender justice at all levels.

\section{National Commitments}

1. Women Issues in Development Plans

The Government of Nepal has implemented a number of rules, laws, policies, and structural reform to support the nation's pursuit of gender justice. The sixth national five-year plan ${ }^{42}$ marked the first explicit focus of women in national policy. This five-year plan sought to integrate women into different programs and projects, recognizing legal barriers to economic empowerment, and setting out special programs to ensure their inclusion. ${ }^{43}$ The Ninth Plan ${ }^{44}$ implemented a three-pronged strategy focusing on gender mainstreaming, eradicating gender inequality, and empowering women. Following in this vein, the Tenth $\mathrm{Plan}^{45}$ set out three strategies for implementation, namely mainstreaming, gender equality, and empowerment to strengthen the status of women vis-à-vis men. ${ }^{46}$

The Three-Year Interim Plan ${ }^{47}$ emphasized the need for establishing a genderinclusive and equitable society, combatting discrimination and violence against women, and providing social integration for conflict-affected women. The latest, 15th Development Plan ${ }^{48}$, established a vision for a gender-egalitarian nation. This plan focuses on removing all forms of discrimination, abuse, and oppression against women, institutionalizing gender-responsive governance. Through these development plans, the Nepal Government seeks to eliminate gender discrimination at all levels.

\section{Women Issues in Constitution}

The Constitution of the Kingdom of Nepal $1990^{49}$ states that no one shall be discriminated against based on sex and that special arrangements shall be laid down for the protection and advancement of the welfare of women. The Interim Constitution of

\footnotetext{
${ }^{42}$ National Planning Commission, "Sixth five-year plan (1980-1985)" (Kathmandu: National Planning Commission, 1980), https://bit.ly/2ICGNEs.

${ }^{43}$ G. Subedi, Population and social justice: Concept, theories and empirical evidences (Kathmandu: Kriti Prakashan, 2010).

44 National Planning Commission, "Ninth plan (1997-2002)" (Kathmandu: National Planning Commission, 1997), https://bit.ly/31Aex44.

45 National Planning Commission, "Tenth plan (2002-2007)" (Kathmandu: National Planning Commission, 2002), https://bit.ly/2IDzBIB.

${ }^{46}$ Subedi, Population and social justice: Concept, theories and empirical evidences.

${ }^{47}$ National Planning Commission, "Three-year interim plan (2007/08-2009/10)" (Kathmandu: National Planning Commission, 2007), https://bit.ly/3lxOEln.

${ }^{48}$ National Planning Commission, "15th development plan (2019/20-2023/24)" (Kathmandu: National Planning Commission, 2019), https://bit.ly/32ISEYY.

${ }^{49}$ Government of Nepal, Constitution of the Kingdom of Nepal 1990 (Kathmandu: Government of Nepal, 1990), Article II, https://bit.ly/2Izl5Pi.
} 
Nepal 2007 went further to address non-sexual discrimination; reproductive rights; protection against violence; equal rights and access to ancestral property; education; social security rights; equality; social justice; and representation in state institutions and civil service based on proportionate inclusion. The second amendment of the Civil Service Act 1993 guaranteed 33 percent of seats filled by women. ${ }^{50}$

The 2015 Constitution of Nepal further developed efforts to establish an equitable society founded on proportional inclusivity and participatory values to ensure economic equality, stability, and social justice by removing all forms of discrimination based on personal attributes, including gender. This constitution enshrines the protection of women's fundamental rights under Article 38. The Article explicitly discusses reproductive rights, prohibition of all forms of violence and exploitation, equal access to property and family affairs, access to education, employment, social security, and participation in all entities of the state. The constitution guaranteed that one third of the total number of elected representatives from each political party represented in the Federal Parliament must be women. ${ }^{51}$ It also envisaged the creation of a National Women's Commission. ${ }^{52}$ Directive Principles, Policies, and Obligations of the State (Part-4) highlighted policies relating to social justice and inclusion. It also has several provisions relating to gender justice. Several other policies - the Gender Equality Act 2006, Domestic Violence (Offence and Punishment) Act 2009 - and good practices - Gender Responsive Budgeting, Gender Audit - support Nepal's commitment to ensuring gender justice.

\section{METHODOLOGY}

Data for this study has been taken from the Nepal National Governance Survey 2017/1853, carried out by Nepal Administrative Staff College and with the technical assistance of the Central Bureau of Statistics, Nepal. The NNGS 2017/18 sampled 12,920 Nepali adults aged 18 years and older across 43 districts of Nepal, using four-stage multiple cluster sampling designs. The overall response rate was $99.6 \%$, whereby a total of 12,872 individuals were successfully interviewed from December 2017 to March 2018. In the NNGS 2017/18, people were asked: 'have you, or a family member of yours, experienced gender-based discrimination within the past 12 months?' There were four available responses to this question: (1) frequently; (2) sometimes; (3) never; and (4) can't say/don't know. One-hundred and five participants responded 'can't say/don't know' and were consequently removed from the study. The analysis of the study is, therefore, delimited to 12,767 individual respondents.

\footnotetext{
50 Anil Kumar Gupta, Gobinda Bhandari, dan Shushma Manandhar, "Representative Bureaucracy in Nepali Civil Service: Exploring the Encounters of Women," Journal of Asian Review of Public Affairs and Policy 5, no. 1 (18 Maret 2020), http://dx.doi.org/10.222.99/arpap/2020.64.

${ }^{51}$ Government of Nepal, Constitution of Nepal 2015 (Kathmandu: Government of Nepal, 2015), Article 84(8), https://bit.ly/2IqkaUj.

${ }^{52}$ Government of Nepal, Article 252.

${ }^{53}$ Nepal Administrative Staff College, "Nepal national governance survey 2017/18."
} 
The study variables were divided into two groups: predictor and outcome. The experience of gender-based discrimination was treated as an outcome variable and socio-demographics (gender, urban/rural, age, education, and economic status) were treated as a predictor variable. Logistic regression was used to create a model for predicting the probability of an individual or their family members experiencing gender-based discrimination. Gender discrimination experience was classified into binary variables [Frequently and Sometimes =1 (Yes, experience gender-based discrimination) and Never $=0$ (No, not experienced gender-based discrimination)]. The Logistic Regression Equation:

$\operatorname{Ln}[\mathrm{P} /(1-\mathrm{P})]=\alpha+\beta \mathrm{X}_{1}$ (gender) $+\beta \mathrm{X}_{2}($ urban $/$ rural $)+\beta \mathrm{X}_{3}($ age $)+\beta \mathrm{X}_{4}($ education $)+$ $\beta \mathrm{X}_{5}$ (economic status).

Where $\mathrm{P}$ is the likelihood of experiencing gender-based discrimination; (1-P) is the likelihood of not experiencing gender-based discrimination; = the constant of the equation and $\mathrm{P} /(\mathrm{l}-\mathrm{P})$ is the "Odds Ratio." The likelihood of experiencing gender-based discrimination is $\mathrm{P}=\operatorname{Exp}(+\mathrm{X}) /(1+\operatorname{Exp}(+\mathrm{X}))$. Conversely, the probability of not experiencing gender-based discrimination is $1-\mathrm{P}=1 /[1+\operatorname{Exp}(+\mathrm{X})]$.

The slope represents the ratio of the probability of experiencing gender-based discrimination to the probability of not experiencing gender-based discrimination compared against each comparison group. The statistical significance was set at $\mathrm{p}<0.05$, and analysis was carried out using SPSS version 26. The odds ratio was stated in this analysis. More than 1 odd ratio for predictor variables indicates positive effects on the outcome variables and vice versa.

\section{RESULTS}

The distributions of the sample population are shown in Table 1. Male and rural municipalities are slightly underrepresented in the sample (47.7\% male and $46.5 \%$ rural municipality). The lowest group is comprised of age groups 18-24 (15.1\%) and 60 and above (17.4\%), while age groups 25-39 and 40-59 are more or less equally distributed. The majority of survey respondents reported that they have no formal education (37.4\%). Basic and secondary education were the most common levels of schooling completed by respondents (59.34\%), with higher education accounting for just $1.6 \%$ of the total sample. The majority of respondents are of medium economic class $(60.9 \%)$, followed by poor $(37.5 \%)$, and rich (1.6\%).

Table l: Sample Distribution

\begin{tabular}{lcc}
\hline & Number & Percentage \\
\hline Sample size & 12872 & 100.0 \\
Gender & & \\
Male & 6145 & 47.7 \\
Women & 6727 & 52.3 \\
\hline
\end{tabular}




\section{Urban/Rural}

Municipality

Rural municipality

\section{Age Group}

18-24

1683

\section{Education}

No education

No formal education

Basic education

2728

Secondary education

\section{Economic Status}

$\begin{array}{lcc}\text { Rich } & 210 & 1.6 \\ \text { Medium } & 7836 & 60.9 \\ \text { Poor } & 4826 & 37.5\end{array}$

Source: Nepal National Governance Survey 2017/18

Table 2 shows the logistic regression coefficient beta ( ) and odds ratio for each variable category. Several remarkable results have been found. Gender discrimination is divergent in intensity and varies across demographics (gender, urban/rural, age, education, and economic status) at a micro-level. Women ( $\mathrm{OR}=2.386, \mathrm{P}<0.05)$ are more likely to report having experienced, or seen a family member experience, gender discrimination (hereafter referred as 'experience gender-based discrimination') in the past 12 months. Citizens living in rural municipalities ( $\mathrm{OR}=1,176, \mathrm{P}<0.05)$ are more likely to report gender-based discrimination than those living in municipalities. This indicates that citizens of municipalities are less affected by gender-based discrimination than those who residence in more rural municipalities. By age, citizens aged 25-39 years $(\mathrm{OR}=1.155, \mathrm{P}>0.05)$ are more likely to report the experience of genderbased discrimination compared to those aged 18-24 and respondents aged 40-59 years $(\mathrm{OR}=.949, \mathrm{P}>0.05)$ and 60 years and older $(\mathrm{OR}=.594, \mathrm{P}<0.05)$ are less likely to report the experience of gender based discrimination.

Citizens with no formal education, basic education, secondary education, and higher education are less likely to report experience of gender-based discrimination compared to those with no education. However, there does not appear to be a clear link between level of education attained and the experience of gender-based discrimination beyond this. Less gender based discrimination is observed for basic education $(\mathrm{OR}=.693, \mathrm{P}<0.05)$, followed by secondary education $(\mathrm{OR}=.753, \mathrm{P}<0.05)$, non-formal education $(\mathrm{OR}=.854, \mathrm{P}>0.05)$ and higher education $(\mathrm{OR}=.973, \mathrm{P}>0.05)$. This suggests that no educated citizen reports more experience of gender-based discrimination. Compared 
to rich citizens, medium $(\mathrm{OR}=.465, \mathrm{P}<0.05)$ and poor citizens $(\mathrm{OR}=.644, \mathrm{P}>0.05)$ are less likely to report experience of gender-based discrimination. This evidence indicates that experience of gender-based discrimination differs by demographic characteristics of citizens.

Table 2. Odds ratios for logistic regression models of gender discrimination

\begin{tabular}{|c|c|c|c|}
\hline Predictor Variables & B & S.E & Odds Ratio \\
\hline \multicolumn{4}{|l|}{ Gender } \\
\hline \multicolumn{4}{|l|}{ Male (Ref.) } \\
\hline Women & .870 & .064 & $2.386^{*}$ \\
\hline \multicolumn{4}{|l|}{ Urban/Rural } \\
\hline \multicolumn{4}{|l|}{ Municipality (Ref.) } \\
\hline Rural Municipality & .162 & .056 & $1.176^{*}$ \\
\hline \multicolumn{4}{|l|}{ Age Group } \\
\hline \multicolumn{4}{|l|}{ 18-24 (Ref.) } \\
\hline $25-39$ & .144 & .099 & $1.155^{* *}$ \\
\hline $40-59$ & -.053 & .108 & $.949 * *$ \\
\hline 60 and above & -.521 & .130 & $.594^{*}$ \\
\hline \multicolumn{4}{|l|}{ Education } \\
\hline \multicolumn{4}{|l|}{ No education (Ref.) } \\
\hline No formal education & -.158 & .083 & $.854^{* *}$ \\
\hline Basic education & -.367 & .090 & $.693^{*}$ \\
\hline Secondary education & -.284 & .099 & $.753^{*}$ \\
\hline Higher education & -.028 & .163 & $.973 * *$ \\
\hline \multicolumn{4}{|l|}{ Economic Status } \\
\hline \multicolumn{4}{|l|}{ Rich (Ref.) } \\
\hline Medium & -.765 & .190 & $.465^{*}$ \\
\hline Poor & -.441 & .193 & $.644^{* *}$ \\
\hline Constant & -1.816 & .232 & .163 \\
\hline
\end{tabular}

${ }^{*} P<0.05$ and ${ }^{* *} p>0.05$

\section{DISCUSSION}

Discrimination against women is deeply embedded in Nepal, its history is saturated with marginalization and gender injustice. Hamal Gurung ${ }^{54}$ highlights that critical drivers of gender-based discrimination in Nepal are the patriarchal, patrilineal and patrifocal' norms that permeate all levels of society. Women and girl's traditional position within Nepal's patriarchal society has been one of inferiority. ${ }^{55}$ The influence

\footnotetext{
${ }^{54}$ Hamal Gurung, "Sex Trafficking and the Sex Trade Industry: The Processes and Experiences of Nepali Women," Journal of Intercultural Studies 35, no. 2 (26 Maret 2014): 163-81, https://doi.org/10.1080/07256868.2014.885415.

55 Susann Rothe, "Gender Discrimination in Nepal and How Statelessness Hampers Identity Formation" (Netherlands: Institute on Statelessness and Inclusion, 2015), https://bit.ly/36zzt4X.
} 
of patriarchy in Nepali society has led to injustice, underrepresentation, exploitation, and discrimination against women in all spheres of society. ${ }^{56}$ According to Shrestha and Gartoulla ${ }^{57}$, around 90 percent of respondents reported that patriarchal culture led to gender disparity in Nepali society. While some statistics reflect the improvements made in women's status in recent years it is difficult to determine whether this is evidence of progress toward gender justice. Gender-based discrimination is still prevalent in Nepali society, and a substantial portion of women continue to experience subjugation, abuse, and exploitation on a daily basis. Discrimination against women is pervasive and systemic, and has strong cultural and historical origins.

Women in Nepal have historically faced discrimination based on gender, caste, ethnicity, and geographical location. ${ }^{58}$ This discrimination is based on a particular gender identity that is strongly linked to socially formed, predefined gender identities. ${ }^{59}$ In Nepal, socio-cultural customs, values, and norms uphold the pervasive patriarchal gender order, where male family members often exercise control over the lives of women who are suppressed and victimized by discriminator ideologies. Men possess more power and opportunities than women in both private and public life. Patriarchy encourages male superiority in all aspects of life, including the spiritual, physical, social, and personal arenas. ${ }^{60}$ It is a system that limits women through male control whose history exceeds national and cultural boundaries. ${ }^{61}$ Patriarchy supports a hierarchical system in which men have authority over women. Within this system men are indoctrinated to expect and ensure this authority women while women are conditioned into submissive and obedient roles, typically limited to the domestic sphere. ${ }^{62}$ Patriarchal gender ideologies and practices create vicious cycles of discrimination. Gender ideologies are conditioned to reinforce the patriarchal status quo. The majority of women continue to live as second-class citizens, they are vulnerable to exclusion and subjugation and have fewer opportunities to exercise autonomy how to live their lives. Deeply ingrained traditional cultural norms and practices contribute to the

\footnotetext{
${ }^{56}$ Sujata Paudel, "Women's Concerns within Nepal's Patriarchal Justice System," Ethics in Action 5, no. 6 (2011): 30-36.

${ }^{57}$ Shrestha dan Gartoulla, "Socio-cultural Causes of Gender Disparity in Nepalese Society."

58 Meena Acharya, "Goal 3: Promote gender equality and empower women," Achieving Millennium Development Goals: Challenges for Nepal. Achieving Millennium Development Goals: Challenges for Nepal 15, no. 49 (2006): 48; Rita Manchanda, "Maoist Insurgency in NepalRadicalizing Gendered Narratives," Cultural Dynamics 16, no. 2-3 (1 Oktober 2004): 237-58, https://doi.org/10.1177/0921374004047750.

59 aSharma, "Gender discrimination and status of women in India."r

${ }^{60}$ Wood, "Gender inequality: The problem of harmful, patriarchal, traditional and cultural gender practices in the church."

${ }^{61}$ Loreen Maseno dan Susan M Kilonzo, "Engendering Development: Demystifying Patriarchy and Its Effects on Women in Rural Kenya," International Journal of Sociology and Anthropology 3, no. 2 (2011): $45-55$.

${ }^{62}$ Wood, "Gender inequality: The problem of harmful, patriarchal, traditional and cultural gender practices in the church."; Wood, "Gender inequality: The problem of harmful, patriarchal, traditional and cultural gender practices in the church."; Acharya, "Goal 3: Promote gender equality and empower women."
} 
discrimination against women, upholding oppressivec patriarchal structures and gender ideologies.

To some extent, women themselves contribute to the perpetuation of the cycles of discrimination that dictate their subjugation by internalising gender biases without acknowledging their discriminatory undertones. ${ }^{63}$ Processes of normalization condition women to accept discrimination as an inherent and unproblematic part of their lives. ${ }^{64}$ As such, many women are not consciously aware of their disadvantaged status because they inherit specific beliefs that entrench and normalize their inferior status. ${ }^{65}$ Women's self-perception is often shaped by traditional cultural and social expectations, values, and attitudes, which limit women's opportunities. ${ }^{66}$ To improve their condition in society women are faced with challenging a deeply ingrained system that is not only dominated by men, but systematically devalues and dismisses women and their role in society due to gender-related stigmas and stereotypes. ${ }^{67}$ Women need to be taken seriously to challenge their oppression and combat social injustice, the more they speak out against injustice, the more they help to reforming and eliminating societal inequity. ${ }^{68}$ Discussions of gender discrimination by socio-demographics are as follows:

\section{A. Gender}

Men and women's perception of gender discrimination varies depending on their gender and related experiences. ${ }^{69}$ Women are more likely to be concerned with gender discrimination than men because it has a more negative impact on their quality of life. Men tend to expernce fewer negative implications of gender discrimination than women do. ${ }^{70}$ This study found that more women than males report experience of

\footnotetext{
${ }^{63}$ Pokharel, "Gender Discrimination: Women Perspective."

64 Rukhshanda Zarar, Muneera Moula Bukhsh, dan Waheed Akbar Khaskheli, "Causes and Consequences of Gender Discrimination against Women in Quetta City," Arts and Social Sciences Journal 8, no. 3 (2017): 1-6.

${ }^{65}$ Abadeer, Norms and Gender Discrimination in the Arab World.

${ }^{66}$ James A Wiggins, Beverly B Wiggins, dan James Wilfrid Vander Zanden, Social psychology (New York: McGraw-Hill, 1994); John P. Fernandez, Racism and Sexism in Corporate Life: Changing Values in American Business, lst edition (Lexington, Mass: Lexington Books, 1981)

${ }^{67}$ Adhikari, "Gender Inequality and the Problem with Girls' School Attendance in Nepal : A Qualitative Perspective of Patriarchal Nepalese Practice (Unpublished Master's Thesis)."

${ }^{68}$ Wood, "Gender inequality: The problem of harmful, patriarchal, traditional and cultural gender practices in the church."

${ }^{69}$ Barbara A. Gutek, Aaron Groff Cohen, dan Anne Tsui, "Reactions to perceived sex discrimination," Human Relations 49, no. 6 (1996): 791-813, https://doi.org/10.1177/001872679604900604; James E. Cameron, "Social identity, modern sexism, and perceptions of personal and group discrimination by women and men," Sex Roles: A Journal of Research 45, no. 11-12 (2001): 743-66, https://doi.org/10.1023/A:1015636318953.

${ }^{70}$ Sharon Foley, Hang-yue Ngo, dan Raymond Loi, "Antecedents and Consequences of Perceived Personal Gender Discrimination: A Study of Solicitors in Hong Kong," Sex Roles 55, no. 3-4 (6 Desember 2006): $197-208$
} 
gender based discrimination, providing further support of this statement. All negative and conventional gender social practices are applicable to women not to men. Social practices create unequal power relationships in which men control and dominate women who are treated women as subordinate.

Patriarchal structures maintain and reinforce male privilege, subjecting women to prejudice and discrimination. ${ }^{71}$ Women are the primary victims of gender discrimination, this is reflected in their higher reporting rates in comparison to men. This is not to say that men do not experience or report gender discrimination, but that they do so at a significantly lower level than women. ${ }^{72}$ Women in Nepal endure gender discrimination because of traditional social and cultural practices that unfairly treat women in comparison to men. These socio-cultural values and practices favour traditional gender roles, which reproduce and expand men's dominance over women. Therefore, women report more gender discrimination than men.

\section{B. Urban/Rural}

Women experience inequality, discrimination, and exploitation everywhere. ${ }^{73}$ Even though gender roles are slowly changing, it has been concentrated more in rural areas. Rural women's condition is considerably lower than their urban counterparts. Citizens in rural municipalities reported higher rates of gender-based discrimination than their urban counterparts. In rural Nepal, one in four young women had been physically assaulted in the last 12 months. ${ }^{74}$ The Nepal Demographic Health Survey ${ }^{75}$, notes that gender discrimination is more prevalent in rural areas $(23.8 \%)$ compared to urban areas (20.5\%). In rural areas, more women have witnessed physical, sexual, or emotional violence (14.5\%) than in urban areas (12.9\%).

This evidence suggest that rural women experience more violence than urban women. Discriminatory traditional cultural values, customs, and practices that devalue girls and women are more deeply entrenched in rural areas, fuelling further discrimination and violence. ${ }^{76}$ These beliefs are influenced by hegemonic, patriarchal ideologies and practices that reinforce gender-based discrimination in rural areas.

\section{Age group}

\footnotetext{
${ }^{71}$ Richard T. Schaefer, Racial and Ethnic Groups (New York: Longman, 1998).

${ }^{72}$ Charles B. Thomas, "Characteristics correlated with perceptions of gender inequality," Michigan Sociological Review 15 (2001): 10-28.

${ }^{73}$ Rao, Sociology : Principles of Sociology with an Introduction to Social, 813.

${ }^{74}$ Rao, Sociology : Principles of Sociology with an Introduction to Social, 813.

${ }^{75}$ Ministry of Health- MOH/Nepal, New ERA/Nepal, dan ICF, "Nepal Demographic and Health Survey 2016."

${ }^{76}$ Gupta, Bhandari, dan Manandhar, "Representative Bureaucracy in Nepali Civil Service: Exploring the Encounters of Women."
} 
Age is a strong predictor of individuals' perception of gender-based discrimination. ${ }^{77}$ Women experience gender discrimination at all ages. While there is some variability with age, it is difficult to determine whether women experience more discrimination at a particular age. Scholars, including Sidanius and Pratto ${ }^{78}$ and Norton and Sommers ${ }^{79}$, assumed that older men (35 years and older) were more likely to have a zero-sum view of gender discrimination in the wake of increasing anti-men bias accompanying a reduction in negative female bias, when compared to younger men (1834 years of age).

As per the Nepal Demographic Health Survey ${ }^{80}$, the physical violence experienced by women increases significantly with age, rising from 11 percent of women aged 15-19, to 28 percent of women aged 40-49. This may be because younger individuals are more likely to resist traditional gender roles and practices and pursue gender equality. Evidence from this study indicates that more young adults reported experience of gender-based discrimination, particularly between the ages of 18 and 39, decreasing after the age of 40 . Younger individuals report more gender discrimination than older. This may be because of higher rates of education, especially among girls, who are more willing to challenge traditional harmful gender customs and practices. Gender discrimination is typically seen as a normal cultural course of action by older individuals, and are less likely to report it than younger.

\section{Education}

Education affects gender discrimination in Nepal. Generally, higher levels of education, both within families and communities, are closely linked to lower reports of gender discrimination. Those with limited education are at higher risk of experiencing gender discrimination. ${ }^{81}$ Shrestha and Gartoulla ${ }^{82}$ observe that seven out of ten respondents strongly agree that illiteracy is one of the major causes of gender disparity in Nepal. ${ }^{83}$ According to the Nepal Demographic Health Survey ${ }^{84}$, the likelihood of experiencing physical violence decreases with higher educational attainment. Thirty-

\footnotetext{
77 Andre Kehn dan Joelle C. Ruthig, "Perceptions of gender discrimination across six decades: The moderating roles of gender and age," Sex Roles: A Journal of Research 69, no. 5-6 (2013): 289-96, https://doi.org/10.1007/s11199-013-0303-2.

${ }^{78} \mathrm{Jim}$ Sidanius dan Felicia Pratto, Social Dominance: An Intergroup Theory of Social Hierarchy and Oppression (New York: Cambridge University Press, 2001).

${ }^{79}$ Michael I. Norton dan Samuel R. Sommers, "Whites See Racism as a Zero-Sum Game That They Are Now Losing," Perspectives on Psychological Science 6, no. 3 (Mei 2011): 215-18.

${ }^{80}$ Ministry of Health- MOH/Nepal, New ERA/Nepal, dan ICF, "Nepal Demographic and Health Survey 2016."

${ }^{81}$ Adeline Delavande dan Basit Zafar, "Gender Discrimination and Social Identity: Experimental Evidence from Urban Pakistan," Staff Reports (New York: Federal Reserve Bank of New York, 2013), https://bit.ly/2H3o7xq.

${ }^{82}$ Shrestha dan Gartoulla, "Socio-cultural Causes of Gender Disparity in Nepalese Society."

${ }^{83}$ Shrestha dan Gartoulla.

${ }^{84}$ Ministry of Health- MOH/Nepal, New ERA/Nepal, dan ICF, "Nepal Demographic and Health Survey 2016."
} 
four percent of women without education witnessed physical violence compared to fewer than one in ten women with SLC or higher education (8\%).

This research found that, opposed to no education, citizens without formal education, basic education, secondary education, and higher education reported fewer gender-based discrimination. This suggests that illiterate citizens experience more gender-based discrimination. Education is a fundamental tool for contesting discriminatory gender ideologies that systematically devalue and harm women. It provides a means of challenging these structures and moving toward a more gender equitable society, supporting women's empowerment.

\section{E. Income}

This study demonstrated that, despite widespread perceptions that gender discrimination is more prevalent among those with lower economic status ${ }^{85}$, citizens with middle and lower economic status reported less gender-based discrimination than their wealthier counterparts. This indicates that gender discrimination occurs regardless of a persons economic status. Deeply ingrained patriarchal ideologies impact everyone in society, perpetuating a social system in which men oppress, subjugate, and exploit women.

\section{CONCLUSION}

This study has demonstrated the pervasice reach of patriarchal ideologies and gender-based discrimination across a whole range of socio-economic indicators in Nepal. Establishing gender equity in a context so deeply entrenched with discriminatory structures is a major task. Gender justice demands the absence of discrimination. Although several measures have been taken against gender-based discrimination by state and non-state actors, patriarchal ideologies remain deeply entrenched in many social structures and practices that put women's lives at risk. The patriarchal customs, values and practices have created an imbalance in power relations which systematically favour men and protect their 'superior' status.

Disrupting this vicious cycle and pursuing gender justice, by eliminating gender inequality and discrimination, is complicated and daunting, but possible. It requires dismantling the hegemonic, patriarchal gender ideology. Progressive and collective action is needed at all levels. Women's empowerment should be prioritized and supported so that they are able to identify, resist, and defend themselves against gender discrimination both proactively as well as reactively. Women must have equal rights and liberty everywhere, and be allowed to live free of abuse, violence, bigotry, and discrimination, as spelt out in the constitution. For this, gender justice should be permanently institutionalized. Everyone, including the government, should have a duty to support the pursuit of gender justice in Nepal.

${ }^{85}$ Zarar, Bukhsh, dan Khaskheli, "Causes and Consequences of Gender Discrimination against Women in Quetta City." 


\section{ACKNOWLEDGEMENT}

The authors would like to thanks Nepal Administrative Staff College for proving Nepal national governance 2017/18 data for this publication.

\section{FUNDING}

This research did not receive any grant from the public, commercial, or not-for-profit sectors.

\section{CONFLICTING INTERESTS}

The authors declared no latent conflicts of interest for publication of this article.

\section{REFERENCES}

Abadeer, Adel SZ. Norms and Gender Discrimination in the Arab World. United States: Palgrave Macmillan, 2015. https://bit.ly/2Va2WAX.

Acharya, Meena. "Goal 3: Promote gender equality and empower women." Achieving Millennium Development Goals: Challenges for Nepal. Achieving Millennium Development Goals: Challenges for Nepal 15, no. 49 (2006): 48.

Adhikari, Bishnu. "Gender Inequality and the Problem with Girls' School Attendance in Nepal: A Qualitative Perspective of Patriarchal Nepalese Practice (Unpublished Master's Thesis)." Nord University, 2013. https://bit.ly/3kx2PFU.

Baral, Balkrishna. "Gender Development Perspective: A Contemporary Review in Global and Nepalese Context." Geographical Journal of Nepal 10 (31 Mei 2017): 14152. https://doi.org/10.3126/gjn.vl0i0.17395.

Barlas, Asma. "Believing women" in Islam: unreading patriarchal interpretations of the Qur'ān. 1st ed. United States: University of Texas Press, 2002. https://bit.ly/36wBFu8.

Cameron, James E. "Social identity, modern sexism, and perceptions of personal and group discrimination by women and men." Sex Roles: A Journal of Research 45, no. 1112 (2001): 743-66. https://doi.org/10.1023/A:1015636318953.

Delavande, Adeline, dan Basit Zafar. "Gender Discrimination and Social Identity: Experimental Evidence from Urban Pakistan.” Staff Reports. New York: Federal Reserve Bank of New York, 2013. https://bit.ly/2H3o7xq.

Dipboye, Robert L., dan Adrienne Colella. Discrimination at Work: The Psychological and Organizational Bases. North Carolina: Lawrence Erlbaum Associates Publishers, 2005.

Fernandez, John P. Racism and Sexism in Corporate Life: Changing Values in American Business. lst edition. Lexington, Mass: Lexington Books, 1981. 
Foley, Sharon, Hang-yue Ngo, dan Raymond Loi. "Antecedents and Consequences of Perceived Personal Gender Discrimination: A Study of Solicitors in Hong Kong." Sex Roles 55, no. 3-4 (6 Desember 2006): 197-208.

Giddens, Anthony. Sociology. Cambridge: Polity Press, 1993.

Government of Nepal. Constitution of Nepal 2015. Kathmandu: Government of Nepal, 2015. https://bit.ly/2IqkaUj.

_- Constitution of the Kingdom of Nepal 1990. Kathmandu: Government of Nepal, 1990. https://bit.ly/2Izl5Pi.

Gupta, Anil Kumar. "Significance of Girl Education: Parents' Perception from Rural Madhesh of Nepal." Journal of Management and Development Studies 29 (28 September 2019): 61-68.

Gupta, Anil Kumar, Gobinda Bhandari, dan Shushma Manandhar. "Representative Bureaucracy in Nepali Civil Service: Exploring the Encounters of Women." Journal of Asian Review of Public Affairs and Policy 5, no. 1 (18 Maret 2020). http://dx.doi.org/10.222.99/arpap/2020.64.

Gurung, Hamal. "Sex Trafficking and the Sex Trade Industry: The Processes and Experiences of Nepali Women." Journal of Intercultural Studies 35, no. 2 (26 Maret 2014): 163-81. https://doi.org/10.1080/07256868.2014.885415.

Gutek, Barbara A., Aaron Groff Cohen, dan Anne Tsui. "Reactions to perceived sex discrimination.” Human Relations 49, no. 6 (1996): 791-813. https://doi.org/10.1177/001872679604900604.

Kambarami, Maureen. Femininity, Sexuality and Culture: Patriarchy and Female Subordination in Zimbabwe. South Africa: ARSRC, 2006. https://bit.ly/3j9i2hL.

Kehn, Andre, dan Joelle C. Ruthig. "Perceptions of gender discrimination across six decades: The moderating roles of gender and age." Sex Roles: A Journal of Research 69, no. 5-6 (2013): 289-96. https://doi.org/10.1007/sll199-013-0303-2.

King, Anna. "UN Declaration on the Elimination of Violence against Women." Dalam The Encyclopedia of Women and Crime, 1-2. 1-2. American Cancer Society, 2019. http://dx.doi.org/10.1002/9781118929803.ewac0505.

Lamichhane, Prabhat, Mahesh Puri, Jyotsna Tamang, dan Bishnu Dulal. "Women's Status and Violence against Young Married Women in Rural Nepal." BMC Women's Health 11, no. 1 (25 Mei 2011): 19. https://doi.org/10.1186/1472-6874-11-19.

Manchanda, Rita. "Maoist Insurgency in NepalRadicalizing Gendered Narratives." Cultural Dynamics 16, no. 2-3 (1 Oktober 2004): 237-58. https://doi.org/10.1177/0921374004047750. 
Maseno, Loreen, dan Susan M Kilonzo. "Engendering Development: Demystifying Patriarchy and Its Effects on Women in Rural Kenya." International Journal of Sociology and Anthropology 3, no. 2 (2011): 45-55.

Maunganidze, Farai. "Dealing with gender-related challenges: A perspective of Zimbabwean women in the practice of law." Disunting oleh Antonio BelsoMartinez. Cogent Business \& Management 7, no. 1 (1 Januari 2020): 18.

Ministry of Health- MOH/Nepal, New ERA/Nepal, dan ICF. "Nepal Demographic and Health Survey 2016," 1 November 2017. https://bit.ly/2ICGSIg.

Morris, Charles G. Psychology: An Introduction. New Jersey: Prentice-Hall, Inc, 1996.

Nair, Janaki. Women and Law in Colonial India: A Social History. New Delhi: Kali for Women and The National Law School of India, 1996. https://bit.ly/2WF6Pl4.

National Planning Commission. "15th development plan (2019/20-2023/24)." Kathmandu: National Planning Commission, 2019. https://bit.ly/32ISEYY.

___ " "Ninth plan (1997-2002)." Kathmandu: National Planning Commission, 1997. https://bit.ly/3lAex44.

_- " "Sixth five-year plan (1980-1985)." Kathmandu: National Planning Commission, 1980. https://bit.ly/2ICGNEs.

_-_ "Tenth plan (2002-2007)." Kathmandu: National Planning Commission, 2002. https://bit.ly/2IDzBIB.

___ “ "Three-year interim plan (2007/08-2009/10)." Kathmandu: National Planning Commission, 2007. https://bit.ly/3lxOEln.

Nepal Administrative Staff College. "Nepal national governance survey 2017/18." Jawalakhel, Lalitpur: Nepal Administrative Staff College, 2018. https://bit.ly/2K8LFCb.

Njoroge, Nyambura. Gender Justice, Ministry and Healing: A Christian Response to the HIV Pandemic. New North Road London: Progression, 2009. https://bit.ly/2VceinL.

Norton, Michael I., dan Samuel R. Sommers. "Whites See Racism as a Zero-Sum Game That They Are Now Losing." Perspectives on Psychological Science 6, no. 3 (Mei 2011): 215-18.

Omoyibo, KU, dan BI Ajayi. "Understanding gender and global Africa: A critical perspective." Gender and Behaviour 9, no. 1 (28 Juni 2011): 3729-51. https://doi.org/10.4314/gab.v9il.67470.

Paudel, Sujata. "Women's Concerns within Nepal's Patriarchal Justice System." Ethics in Action 5, no. 6 (2011): 30-36.

Pokharel, Samidha. "Gender Discrimination: Women Perspective." Nepalese Journal of Development and Rural Studies 5, no. 2 (1 Januari 2008): 80-87. 
Ram, Usha, Lisa Strohschein, dan Kirti Gaur. "Gender Socialization: Differences between Male and Female Youth in India and Associations with Mental Health." International Journal of Population Research, 27 April 2014, 1-11. https://doi.org/10.1155/2014/357145.

Rao, CN Shankar. Sociology: Principles of Sociology with an Introduction to Social. Chand \& Company Ltd., 2008.

Rothe, Susann. "Gender Discrimination in Nepal and How Statelessness Hampers Identity Formation." Netherlands: Institute on Statelessness and Inclusion, 2015. https://bit.ly/36zzt4X.

Schaefer, Richard T. Racial and Ethnic Groups. New York: Longman, 1998.

Sharma, Indu. "Gender discrimination and status of women in India." Contemporary Social Sciences 27, no. 1 (2018): 105-14.

Shastri, Andrey. "Gender Inequality and Women Discrimination." IOSR Journal of Humanities and Social Science 19, no. 11 (2014): 27-30.

Shrestha, Anita, dan R. Gartoulla. "Socio-cultural Causes of Gender Disparity in Nepalese Society." Journal of Advanced Academic Research 2, no. 1 (2015): 100-111.

Sidanius, Jim, dan Felicia Pratto. Social Dominance: An Intergroup Theory of Social Hierarchy and Oppression. New York: Cambridge University Press, 2001.

Subedi, G. Population and social justice: Concept, theories and empirical evidences. Kathmandu: Kriti Prakashan, 2010.

Sultana, Abeda. "Patriarchy and Women's Subordination: A Theoretical Analysis." Arts Faculty Journal 4 (13 Desember 2012): 1-18.

Thomas, Charles B. "Characteristics correlated with perceptions of gender inequality." Michigan Sociological Review 15 (2001): 10-28.

United Nations. "Conference on women's political rights," 1952. https://bit.ly/2UnJk8e.

——_. "Convention on married women's nationality," 1957. https://bit.ly/2HOybHv.

_- — . "Convention on the elimination of all forms of discrimination against women," 1979. https://bit.ly/2JWVLpx.

_- _. "Declaration on the elimination of violence against women," 1993. https://bit.ly/36xbCCU.

—_— "Millennium development goals," 2000. https://bit.ly/36xxVZf.

__— "Sustainable development goals," 2015. https://bit.ly/3kvtYJp.

___ . "Universal declaration of human rights," 1948. https://bit.ly/3nkd0Qb. 
United Nations Population Found. "International conference on population and development," 1994. https://bit.ly/3kyq0zI.

Wadesango, Newman. "Is Gender Equality Still an Issue? Tensions and Contradictions Embeding the Work of Feminists Today." Journal of Social Sciences 26, no. 3 (1 Maret 2011): 163-69.

Walby, S. Theorizing Patriarchy. Cambridge USA: Blackwell Publisher, 1990. https://bit.ly/3xgw06P.

Wiggins, James A, Beverly B Wiggins, dan James Wilfrid Vander Zanden. Social psychology. New York: McGraw-Hill, 1994.

Wood, Hannelie J. "Gender inequality: The problem of harmful, patriarchal, traditional and cultural gender practices in the church." HTS Teologiese Studies / Theological Studies 75, no. 1 (12 Maret 2019): 8.

World Economic Forum. "Global Gender Gap Report 2020.” Cologny, Switzerland: World Economic Forum, 2020. https://bit.ly/36sE60s.

Zarar, Rukhshanda, Muneera Moula Bukhsh, dan Waheed Akbar Khaskheli. "Causes and Consequences of Gender Discrimination against Women in Quetta City." Arts and Social Sciences Journal 8, no. 3 (2017): 1-6. 